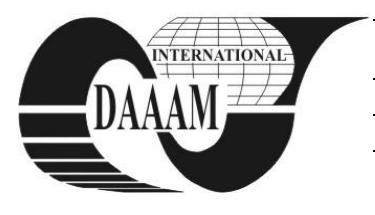

Annals of DAAAM for 2012 \& Proceedings of the 23rd International DAAAM Symposium, Volume 23, No.1, ISSN 2304-1382 ISBN 978-3-901509-91-9, CDROM version, Ed. B. Katalinic, Published by DAAAM International, Vienna, Austria, EU, 2012 Make Harmony between Technology and Nature, and Your Mind will Fly Free as a Bird Annals \& Proceedings of DAAAM International 2012

\title{
THE CONCEPTION OF A PROCESS COST CALCULATION
}

\author{
KOLOSOWSKI, M[ariusz] \& CHWASTYK, P[iotr]
}

\begin{abstract}
The issue of cost calculation of processes pursued in enterprise in the context of effective management of these processes has been carried out in the paper. The essence of process management and difficulties linked with measurement and improvement of processes in organizations have been described. Next the discussion concerns the imperfection of traditional methods of cost calculation. The cost calculation method based on Activity Based Costing has been proposed to enable precise processes cost determination together with its structure and continuous improvement of these processes. Finally, benefits and difficulties related to the implementation of the proposed method have been pointed out.
\end{abstract}

Keywords: process, activity, cost, activity based costing, process improvement

\section{INTRODUCTION}

Quality systems in contemporary organizations are generally based on the ISO 9000 guidelines. Rising number of enterprises all over the world prefer ISO 9001 certified suppliers and co-operators. Business contracts often are being preceded with the review of the quality manuals. Complying with requirements included in quality standards assures recipients of high capability of suppliers of products and services to fulfill quality requirements. ISO 9000:2000 and 2008 editions put special emphasis on the process approach. That means the necessity of identifying processes in organization an managing them. As long as the identification of processes in organizations does not make great problems, in so far as describing appropriate measuring instruments often seems to be more troublesome, by means of which the analyzed processes are monitored and improved.

Large number of methods of processes analyzing and assessment is based on the process cost, so it is necessary to use up-to-date and accurate management accounting tools, including advanced cost calculation methods. Standing cost account, based on traditional, division and additional calculation methods, specifies only material cost, labour cost and overhead. Then, cost analysis is limited only to these cost areas [4].

Tendencies in the market economy development, such as keener competition, closer cooperation and global market, changes referring to technology and automation of production processes, increasing the range of products and shortening their life cycle, caused changes in the enterprises cost structure. Contemporary business is characterized by high share of indirect cost within production total cost. Moreover, that share shows permanently an increasing trend. That is why traditional methods of cost calculation provide inexact information that contribute to make mistaken decision. More over, described tendencies require knowing exact values of all cost components related to manufacturing process, the total cost of manufactured products and, of course, the cost of particular processes in enterprise. Traditional cost calculation methods do not make it possible $[4,7]$.

Costs of processes are not recorded in separate accounts in the traditional financial accountancy, that is why it should be carefully selected out of the other items passed in the system. It is one of the main reasons that reliable estimation of quality assurance processes costs in enterprises is not common [8]. This problem seems to touch other processes in organizations too. It is obvious that without precise cost information full description of effectiveness of the realized actions is impossible. That is why to put in practice the guidelines of the process approach by introducing processes measurement, for example based on the balanced scorecard, it is necessary to apply an appropriate method enabling to gain suitable cost data and its transformation into usable information from improvement of processes point of view.

\section{THE ESSENCE OF PROCESS ORIENTED MANAGEMENT}

Turbulent business environment entails the necessity of changing methods of management in present times. Contemporary conditions of enterprises functioning in varaible surrounding, above all both intensifying competition and occurred changes dynamics, set new tasks in range of high quality products, increasing efficiency of business processes simultaneously aiming at decreasing the costs of production and shortening production cycles. As a result of such situation in enterprises is most often restructuring which is usually connected with dismissals, changes of organizational structures, legal status, implementation of expensive information system, asset sales, etc. But as the researches show, only $25-30 \%$ enterprises assess that kind of shortterm fixation brought positive results. Due to I. Durlik, traditional restructuring gradually allows to achieve technical and organizational progress in limits 5-10 percent annually, with successive revamping of organizational structures and management improvement. This improvement is most often connected with computerization and partial automation of management processes and production of processes created in traditional condition of information processing [1].

A chance for radical change manifesting itself first and foremost in better results, is precise analysis of processes appearing in organization, reorganization and continuous perfection. Great popularity in 90's gained Business Process Reengineering (BPR) which main 
guideline is to make radical changes of hierarchic organization structure into horizontal, based on processes not on functions $[1,4,9]$.

Reengineering put an emphasis on breakage with the old rules of organization and designing all processes in every area of enterprise. We cannot focus only on technological processes. Such conception establishes redesigning of comprehensive processes i.e. concentrated both on internal and external customer service [1].

Radical changes are not registered in the TQM philosophy, which is based on the Kaizen continuous improvement principle. Such perceptible orientation of improvement of processes assembles also the series of ISO 9000:2000 and later standards. According to these norms, the process approach is a "systematic identification and management of the processes employed within an organization and particularly the interactions between such processes", whereas a process is a "set of interrelated or interacting activities which transforms inputs into outputs" [6].

According to ISO 9001 standard, in order to implement and maintain a quality management system, the organization should [6]:

1) Identify the processes needed for the quality management system.

2) Determine the sequence and interaction of these processes.

3) Determine criteria and methods needed to ensure that both the operation and control of these processes are effective.

4) Ensure the availability of resources and information necessary to support the operation and monitoring of these processes.

5) Monitor measure and analyze these processes, and implement actions necessary to achieve planned results and continual improvement of these processes.

Adaptation to the process approach assumptions entails the necessity of changes in the organizational structures of enterprises. Most of the management systems in Polish enterprises are based on functional structures. The crucial disadvantage of these structures is the fact that they reflect only the functions of organizations, but not the processes, that cut the borders of functional cells.

Process approach requires glance on fundamental business processes from transfunctional perspective, that is across various functional divisions traditionally formed in enterprises [1,4]. It forced development of new forms of organizational structures, as network or process structures. In enterprises organized around processes, basic organizational units are processes teams, directed on meeting internal and external customer needs. Processes runs horizontally through functional structure, as opposed to vertical labour division which is the base of traditional approaches towards organization managements [4].

Mainly the Total Quality Management conception contributed to proceeding development of organizational structure in which teams play the main part. The necessity of quick reaction on market signals (customer needs), introducing information technology, and team work determines organizational structure compressing. In practice, passage from functional to process deception is not easy, because the concentration on processes leads to disrobement of former division for functions and specialties, for the benefit multifunctional employee's teams, made for the specific processes needs. It should also be pointed that process orientation is not only a change of an organizational structure, but mainly development of organizational culture, as much as improvement of the abilities of team work among employees.

\section{THE PROPOSAL OF THE COST CALCULATION METHOD}

Transfunctional character of pursued process in enterprises make traditional methods of cost calculation being not enough to gain precise cost data connected with these processes. Activity Based Costing (ABC) characterize with greater possibilities of describing cost of making particular actions, than division and additional methods, where bigger part of costs is calculated on cost drivers in averaged way or in the spread form. Moreover, traditional cost calculation methods do not enable determining cost of particular processes in enterprise, so improving processes is much more difficult. Implementing Activity Based Costing enables avoiding difficulties mentioned above [4].

That is why, the model of the cost calculation method based on the ABC method has been worked out. The proposed method includes four stages of proceeding:

1) Circumscribing the structure of the production process - selecting implemented activities.

2) Establishing the activities outputs.

3) Establishing activities outputs measures.

4) Assigning activities cost to products and calculating products cost.

The fundamental assumption of Activity Based Costing is that not products but activities implemented in organizations are directly responsible for generating cost. Selecting activities in enterprise is a starting point of calculation accordingly the ABC method. According to ISO 9001:2008 standard, ,any activity, or set of activities, that uses resources to transform inputs to outputs can be considered as a process" [6]. Activities may be selected using quality system procedures, production process documentation (production orders), technological documentation (technology cards, processing instructions), interviews and research conducted in the enterprise.

Activities of the production processes in enterprise may be divided into direct and indirect activities. Direct activities participate in the production process route directly. Indirect activities support direct activities and other indirect activities. Accounting cost of activities starts from the indirect activities, divided into levels, up to direct activities as it has been described [3]. Cost of activity is assigned to other activities according to the number of units of its output measure.

Exemplary structure of production process route with specified direct and indirect activities has been show in the figure 1 . 


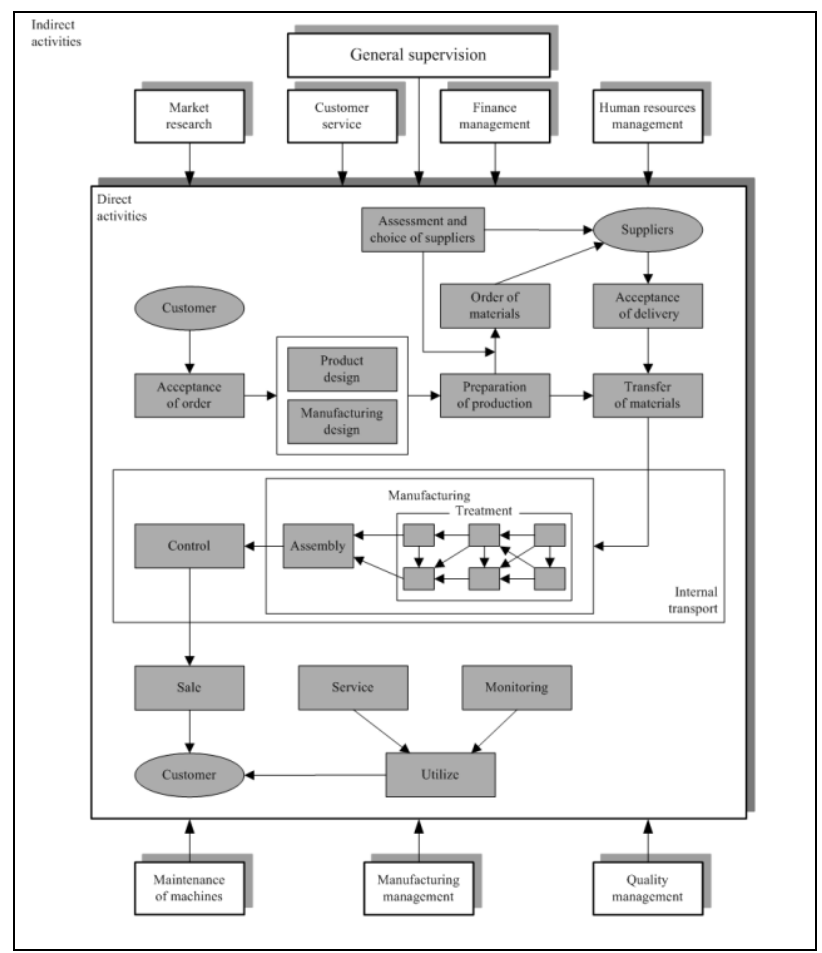

Fig. 1.Exemplary structure of production process route with specified direct and indirect activities

Processes in enterprises consist of a number of activities. Before defining activities processes costs, first the cost of the individual cost cell should be defined. To define this, factory accounting sheet, in which intermediate indicating costs are accounted for organizational units in enterprises, may be used. These costs are accounted directly out according to consumption or indirectly according to proper keys of division. In production practice, one action is often made on many cost cells. In the balance sheet of activities for every cost cell one may isolate actions in which this particular cell takes part. The proposal of the balance sheet of activities has been presented in the fig. 2 .

Explanation to the fig. 2 - examples of actions and activities:

- $\mathrm{a}_{\mathrm{D} 412}$ means action "1" included in the direct activity " 4 ", executed in the cost cell " 2 ",

- $\mathrm{a}_{1925}$ means action "2" included in the indirect activity "9", executed in the cost cell " 5 ",

- $A_{D 3}$ means direct activity " 3 ".

After ascribing activities towards cost cells, assigning the indirect prime costs takes place. It is possible to present total process cost as a total cost of activities of this process, while cost of particular activity could be expressed as a total cost of its actions - formulas (1-4):

$$
\begin{gathered}
P_{p}=\left\{A_{p z}\right\} \\
c_{p}=\sum_{z=1}^{Z} c_{p z} \\
A_{p z}=\left\{a_{p z k i}\right\} \\
c_{p z}=\sum_{k=1}^{K} c_{p z k i}
\end{gathered}
$$

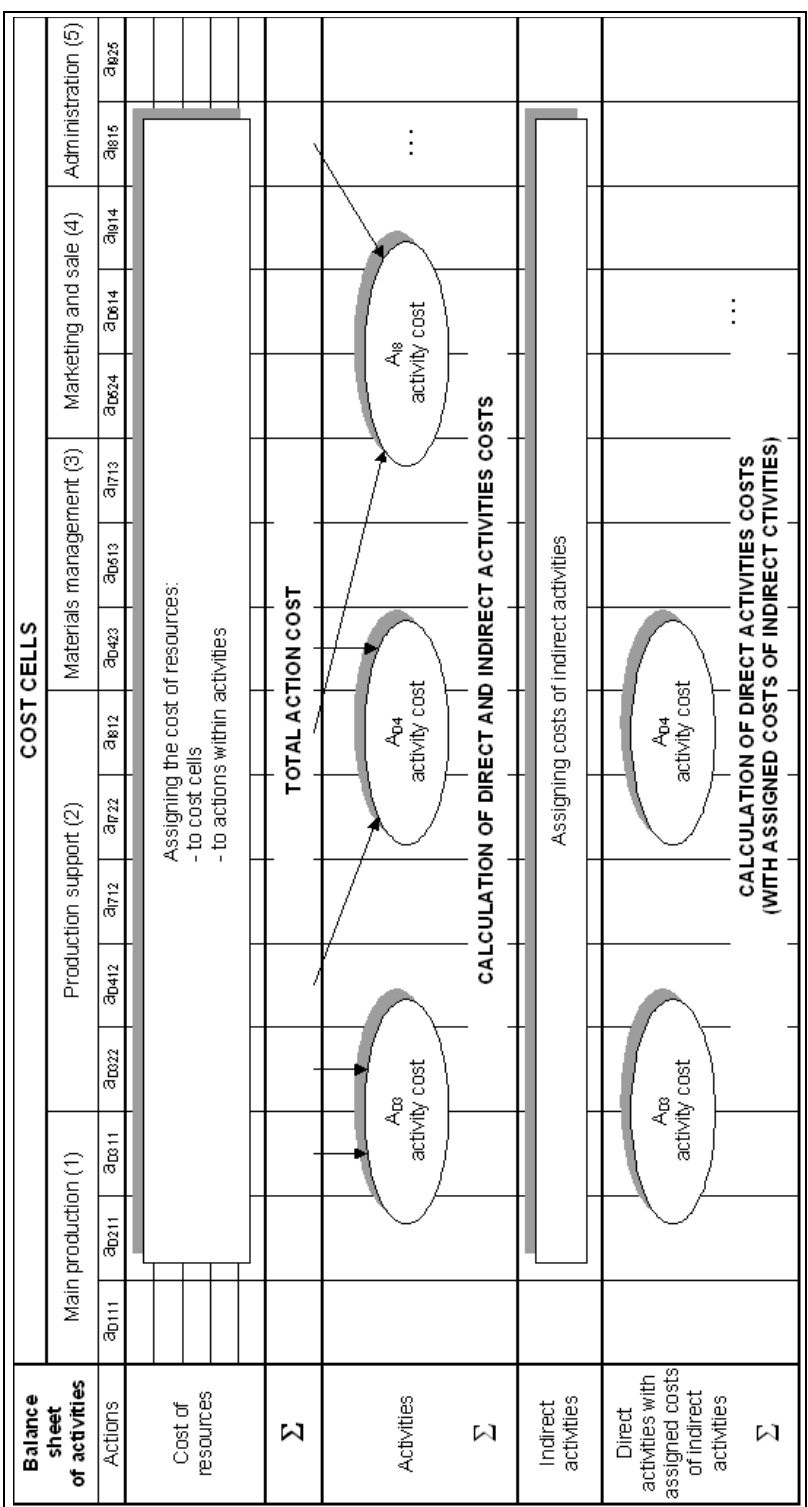

Fig. 2. The balance sheet of activities

where:

$P_{p} \quad-$ process " $\mathrm{p}$ ",

$A_{p z} \quad-\quad$ activity " $\mathrm{z}$ " included in process " $\mathrm{p}$ ",

$c_{p} \quad-$ process " $p$ " cost,

$c_{p z}-$ activity " $\mathrm{A}_{\mathrm{pz}}$ " cost,

$a_{p z k i} \quad-\quad$ action " $\mathrm{k}$ " included in activity " $\mathrm{A}_{\mathrm{pz}}$ ", executed in cell " $\mathrm{i}$ ",

$c_{p z k i} \quad-$ action " $\mathrm{a}_{\mathrm{pzki}}$ " cost.

Next stages are establishing the activities outputs and establishing activities outputs measures. These measures are quantitative indicators of the activities effects . They are the base of assigning activities costs to products. These measures should [5]:

- express the demand of a particular cost object for the activities,

- reflect the causes of costs,

- be understandable and easy to measure,

- compromise between accuracy and cost measurement.

Selecting these measures (distribution keys) is a very difficult task, especially in conditions of diversified production program that is characteristic to piece and small batch production. Nevertheless, appropriately 
selected distribution keys determine accurate cost calculation. So the aim is to compromise between the accuracy of the calculation and the cost of obtaining relevant data.

Assigning cost of resources to cost cells and then to activities executed in enterprise according to proper keys of division has been described in [2, 3].

\section{BENEFITS AND DIFFICULTIES RELATED TO THE IMPLEMENTATION OF THE PROPOSED SOLUTIONS}

The main aim of the process approach is making processes improvement in enterprises possible. That is why processes in organizations should be defined and described as carefully as possible. Process improvement needs introducing process measurement, otherwise criteria of process assessment would not be unambiguous. According to economic aspects of running business, financial measures of processes are especially crucial for business efficiency. Therefore, the proposed method of cost calculation seems to be fully justified. Running process cost account according to ABC method makes taking reasonable decisions connected with processes in enterprise possible. Analyzed processes implemented in organizations supply data to conduct cost calculation according to $\mathrm{ABC}$ method. As a result we get accurate information concerns effectiveness of making an action, amount of bearing costs or processes and actions demanding improvement. This information is used in taking decisions linked with perfecting those processes in enterprise. Cost analysis and advantages connected with processes realization and researches of solutions making a success for enterprises require taking Rummler and Brache's three levels of efficiency into consideration: organization, process and work station [10].

Making the most of possibilities to processes improvement realized in enterprise could be possible thanks to preparing of Activity Based Management system - ABM. This system focuses on processes management and actions in order to rising the value obtained by customer and increasing profits spring into existence thanks to creation of that value. That system should include analysis of factors that generate costs, activities analysis and efficiency measurement.

Cost calculation based on the ABC method has a lot of advantages. It allows to answer following questions:

- Which activities consume specified resources in the organization?

- What is the cost of individual processes and activities of the company?

- Why the organization needs to pursue particular activities and business processes?

- What factors influence the amount of the costs of individual processes and activities?

- What part of activities is due to specific groups of products, services and purchasers of the company products?

- Which activities performed within the process are value added, and which lead to the reduction of the process value?
It is also necessary to mention of limitations of the presented approach in the production practice:

- operation of most enterprises based on traditional functional organizational structure,

- time-consuming process of implementation,

- the correct identification of activities in the organization and defining units of measurement,

- the need for involvement managers of all departments in the preparations for the implementation,

- significant effort and high cost of operation of the $\mathrm{ABC}$ system in organizations,

- the need for continuous updating of the system after implementation.

\section{CONCLUSION}

It should be remembered that despite difficulties mentioned above, associated with implementing and maintaining the cost account system based on the ABC method, detailed cost analysis of particular process phase of production system conducts to minimization total production costs simultaneously meeting demanding of product consumers. It is crucial, so that process analysis should be complex from economic results of enterprise activity point of view and include whole production system. We should move towards obtain possibly beneficial results for whole system, not just for chosen fragment. Complex analysis of processes within production system in enterprise is possible using the presented method. The further step of the research will lead to work out the management accounting system to manage processes and activities to increase the profits. That system should include analysis of factors which would generate cost, activities analysis and efficiency measurement.

\section{REFERENCES}

[1] Durlik, I. (2002). Reengineering and information technology in the restructuring of business processes. WNT, ISBN 83-2042745-2, Warsaw

[2] Kolosowski, M. (2008). Optimization of the Manufacturing Process Route of Machine Components Aided with Activity Based Costing. Annals of DAAAM for 2008 \& Proceedings of the 19th International DAAAM Symposium, Katalinic, B. (Ed.), pp. 717-718, ISBN: 978-3-901509-68-1, ISSN: 1726-9679, Trnava, Slovakia, October 2008, DAAAM International, Vienna, Austria

[3] Kolosowski, M. \& Chwastyk, P. (2011). Cost of Activities in the Quality Cost Account. Annals of DAAAM for 2011 \& Proceedings of the 22nd International DAAAM Symposium, ISBN 978-3901509-83-4, ISSN 1726-9679, pp. 313, Editor B. Katalinic, Published by DAAAM International, Vienna, Austria

[4] Matuszek, J. (2000). Production engineering. Publishing House of Technical University of Lodz, ISBN 83-87087-97-1, BielskoBiala

[5] Nowak, E.; Piechota, R. \& Wierzbinski, M. (2004). Cost account in business management, PWE, ISBN: 83-208-1492-8, Warsaw

[6] PN-EN ISO 9001:2009 (2009). „Quality management systems Requirements". Polish Committee for Standardization

[7] Sobanska, I. (Ed.) (2009). Cost account.Operational and strategic approach, C.H. Beck, ISBN: 978-83-255-0114-3, Warsaw

[8] Szczepanska, K. (2009). Cost of quality for engineers, PLACET, ISBN: 978-83-7488-139-5, Warsaw

[9] Valiris, G. \& Glykas, M. (1999). Critical review of existing BPR methodologies. The need for a holistic approach. Business Process Management Journal, Vol. 5, No. 1, pp. 65-86, ISSN: 1463-7154

[10] Zymonik, Z. (2003). Cost of quality in business management, Publishing House of Wroclaw University of Technology, ISBN: 83-7085-744-2, Wroclaw 